\title{
Dietary exposure of juvenile common sole (Solea solea L.) to polybrominated diphenyl ethers (PBDEs): Part 1. Bioaccumulation and elimination kinetics of individual congeners and their debrominated metabolites
}

\author{
C. Munschy ${ }^{a,}{ }^{*}$, K. Héas-Moisan ${ }^{a}$, C. Tixier $^{a}$, N. Olivier ${ }^{a}$, O. Gastineau $^{b}$, N. Le Bayon ${ }^{b}$ and V. Buchet ${ }^{b}$
}

a Institut Français de Recherche pour l'Exploitation de la Mer (IFREMER), Laboratory of Biogeochemistry of Organic Contaminants, Rue de l'lle d'Yeu, BP 21105, 44311 Nantes Cedex 3, France

${ }^{\mathrm{b}}$ Institut Français de Recherche pour l'Exploitation de la Mer (IFREMER), Laboratory of Adaptation, Reproduction and Nutrition of marine fish, BP 70, 29280 Plouzané, France

* Corresponding author : C. Munschy, email address : cmunschy@ifremer.fr

\begin{abstract}
:
The uptake and elimination of six PBDE congeners (BDE-28, -47, -99, -100, -153, -209) were studied in juvenile common sole (Solea solea L.) exposed to spiked contaminated food over a three-month period, then depurated over a five-month period. The results show that all of the studied PBDEs accumulate in fish tissues, including the higher brominated congener BDE-209. Several additional PBDE congeners were identified in the tissues of exposed fish, revealing PBDE transformation, mainly via debromination. The identified congeners originating from PBDE debromination include BDE-49 and BDE-202 and a series of unidentified tetra-, penta-, and hepta- BDEs. Contaminant assimilation efficiencies (AEs) were related to their hydrophobicity $\left(\log K_{o w}\right)$ and influenced by PBDE biotransformation. Metabolism via debromination appears to be a major degradation route of PBDEs in juvenile sole in comparison to biotransformation into hydroxylated metabolites.

Juvenile sole exposed to artificially-contaminated food accumulate PBDEs, including the higher brominated congeners, and have a debromination capacity.
\end{abstract}

Keywords: Marine flatfish; PBDEs; Bioaccumulation; Biotransformation; Debromination 


\section{Introduction}

Polybrominated Diphenyl Ethers (PBDEs) have been extensively studied for around a decade, due to the exponential increase of their environmental levels. These compounds have been identified worldwide and in all environmental compartments (de Wit, 2002; Law et al., 2003; Hites, 2004; Law et al., 2006; Tanabe et al., 2008; Shaw and Kannan, 2009). They are also cause for concern due to their potential adverse effects on wildlife and humans (Darnerud et al., 2001; de Wit, 2002; Legler, 2008; Ross et al., 2009). These contaminants may exert toxic effects such as endocrine disruption, alteration of thyroid hormone homeostasis and neurotoxicity (Legler, 2008). Their physicochemical properties and fate in the environment (persistence, bioaccumulation, long-range transport and toxicity) qualify them as persistent organic pollutants (POPs); therefore, commercial Penta-bromodiphenyl ether and Octa-bromodiphenyl ether have been added to the list of POPs established by the United Nations Stockholm Convention since May 2009 (BSEF, 2010). PBDEs also feature on the list of priority substances drawn up by the European Water Framework Directive (Decision 2455/2001/EC).

Over 67,000 metric tons of PBDEs were produced worldwide in 2001, mostly comprising Deca-bromodiphenyl ether (DecaBDE) (over 80\%) (Law et al., 2006). The commercial mixtures Penta-bromodiphenyl ether and Octa-bromodiphenyl ether have been banned from the European market since 2003 (Directive 2003/11/EC) and effectively eliminated in North America since 2005 (Ward et al., 2008). DecaBDE remains on the list of authorized chemicals. However, it has been banned for use in all electrical and electronic applications in Europe since July 2008, and its production and use will be voluntarily phased out in the U.S. market by the end of 2012 (BSEF, 2010). BDE-209, - the main component of DecaBDE - was initially thought to represent a low 
threat to biota due to its high hydrophobicity and high molecular size. However, several studies have demonstrated that this compound is bioavailable and can be transformed into more bioaccumulable and toxic PBDEs (Kierkegaard et al., 1999; Stapleton et al., 2006). Moreover, BDE-209 accumulation in sediment has recently become a matter of concern, as this compartment represents large environmental reservoirs and could therefore be a potential threat to biota in the long-term (Ross et al., 2009). PBDE behaviour in fish has been the focus of several studies. Studies dealing with fish artificially exposed to PBDEs via food have shown that the fate of individual congeners is highly dependent upon the species as well as the congener itself. Fish have widely varying capacities to assimilate and metabolise PBDEs via debromination processes, both in terms of efficiency and metabolite profiles. For example, juvenile carp (Cyprinus carpio) showed no accumulation of BDE-99 following dietary exposure (Stapleton et al., 2004a), whereas juvenile trout (Salvelinus namaycush) (Tomy et al., 2004) and pike (Esox lucius) (Burreau et al., 1997) were shown to accumulate this congener. Different fish species also varied in their ability to transform BDE-99 into BDE-49 or BDE-47 (Stapleton et al., 2004b; Benedict et al., 2007; Browne et al., 2009). Congeners with 3 to 10 bromine atoms were all found to accumulate in juvenile lake trout with varying assimilation efficiencies, widely influenced by debromination (Tomy et al., 2004). BDE-47 generally showed the highest uptake (Burreau et al., 1997; Tomy et al., 2004; Stapleton et al., 2004a), while BDE-209 assimilation by fish was generally low and gave rise to lower brominated congeners. No BDE-209 was found in juvenile carp tissues after a 60-day food exposure experiment, but several penta- to octa-BDEs accumulated in the exposed fish (Stapleton et al. 2004c). BDE-209 was shown to accumulate in the tissues of rainbow trout (Oncorhynchus mykiss) - mainly in the liver - 
and uptake of this congener was around $3 \%$ when all debrominated congeners, mainly octa- and nona-BDEs, were taken into account (Stapleton et al., 2006). This study also revealed that $22 \%$ of BDE-209 was biotransformed in liver microsomes of rainbow trout. In another study, BDE-209 uptake by rainbow trout after 120 days of exposure was reported to be even lower, i.e., in the 0.02-0.13\% range (Kierkegaard et al., 1999). The purpose of our study was to determine accumulation and elimination kinetics, and to identify the metabolites of selected PBDEs in common sole (Solea solea L.) exposed to spiked food under experimental conditions. Common sole was chosen as the target species for this project in view of its benthic habitat and potential exposure to sedimentassociated persistent organic contaminants such as PBDEs, plus its high commercial value on European coasts (Riou et al., 2001; Nicolas et al., 2007). The results presented in this paper are part of a larger project on the fate and effects of selected organic contaminants (PCBs, PBDEs, and PAHs) in juvenile sole. In this paper, we have focused on the accumulation and depuration kinetics of PBDEs and the formation of debrominated congeners. The occurrence of other biotransformation products such as hydroxylated PBDEs has also been studied and the results are presented in a separate paper (Munschy et al., part 2, submitted for publication).

\section{Materials and Methods}

\subsection{Experiment}

The experimental design used for the fish exposure is described in detail in the Supplementary Information (SI). Only the main aspects are summarized below. Juvenile sole (Solea solea L.) obtained from a commercial hatchery (Solea BV, Ijmuiden, Netherlands) were maintained in separate $4 \mathrm{~m}^{2}$ (circa $400 \mathrm{~L}$ ) tanks receiving a 
continuous flow of sea water from the roadstead of Brest (Brittany, France), maintained at $12 \mathrm{~h} \mathrm{light} \mathrm{/} 12 \mathrm{~h}$ dark photoperiods and at a constant temperature $\left(19 \pm 1^{\circ} \mathrm{C}\right)$. The commercial food, obtained from Dan Feed (Denmark), consisted of formulated feed containing 58\% crude protein and 15\% crude fat (DAN-EX 1562, pellet-size $2 \mathrm{~mm}$ ).

Spiked food was prepared by slowly adding a solution in iso-octane of known amounts of six PBDE congeners (i.e., BDE-28, BDE-47, BDE-99, BDE-100, BDE-153, BDE209, AccuStandard ${ }^{\circledR}$ Inc., New Haven, USA, purity above 98\%) to commercial food. Spiked food was stored in amber containers in a cool, dark place throughout its use (circa 1.5 month). Individual PBDE congener concentrations were determined in each batch of spiked food, and mean values were considered for the calculation of Assimilation Efficiencies (AEs). Concentrations of individual congeners were between $82 \pm 5 \mathrm{ng} \mathrm{g}^{-1}$ wet weight (ww) and $93 \pm 6 \mathrm{ng} \mathrm{g}^{-1}$ ww for BDE-28, BDE-47, BDE-99 and BDE-100, $181 \pm 16 \mathrm{ng} \mathrm{g}^{-1} \mathrm{ww}$ and $184 \pm 23 \mathrm{ng} \mathrm{g}^{-1}$ ww for BDE-153 and BDE-209, respectively (mean value \pm standard deviation $-S D-, n=20$ batch replicates, Table 1 ). Non-spiked food was also analysed for PBDE levels, and concentrations were between $<0.005 \mathrm{ng} \mathrm{g}^{-1} \mathrm{ww}$ and $0.39 \mathrm{ng} \mathrm{g}^{-1} \mathrm{ww}$ (mean value calculated on $\mathrm{n}=4$ replicates) depending on the congener. The congeners detected in non-spiked food included the congeners used to spike the contaminated food, plus BDE-49 (0.17 $\left.\mathrm{ng} \mathrm{g}^{-1} \mathrm{ww}\right)$, a nonidentified penta-BDE (Penta-1 at $\left.0.02 \mathrm{ng} \mathrm{g}^{-1} \mathrm{ww}\right)$ and BDE-154 (0.04 $\mathrm{ng} \mathrm{g}^{-1} \mathrm{ww}$ ) (Table $1)$.

The fish ( $\mathrm{n}=470$, one tank) were exposed to food spiked with PBDEs for 84 days, followed by non-spiked food for 149 days. In order to check if the addition of solvent to food had any effect on the study parameters, two types of control fish were considered and separated in between two tanks: one tank corresponded to fish $(n=474)$ fed 
commercial food, and one tank to fish $(\mathrm{n}=492)$ fed commercial food to which solvent (iso-octane) was added. Individual daily feeds were adjusted according to fish size and biomass in each tank throughout the experiment, and were equivalent to $0.8 \%$ of fish body weight / day, on average. In order to minimize uneaten food, this daily feeding rate was slightly reduced compared to those found in the literature for sole grown in captivity (Coutteau et al., 2001; Schram et al., 2006).

Individual fish size and weight were recorded immediately after anaesthesia with phenoxy-ethanol. Fish were sampled from the tank receiving spiked food on days 0,8 , 14, 28, 56, and 84 (contamination period) and on days 91, 98, 112, 140, 168 and 233 (depuration period). Fish from both control tanks were sampled on days $0,14,84,91$, 140, 168 and 233. Fish were then brought to the laboratory for further dissection in clean conditions. Muscle (without skin) and liver were dissected to determine PBDE concentrations. Samples were made from pooled individuals of $n=8$ to 20 , depending on fish size, and replicate pools ( $\mathrm{n}=2$ to 3 ) were generally processed.

This study was conducted under the approval of the Animal Care Committee of France under the official licence (972-1) of V. Buchet. Special attention was given to the treatment of wastes, including water decontamination design (see detailed information in the SI).

\subsection{Sample preparation}

The detailed standards, reagents and analytical protocols for extraction and clean-up have been described previously (Johansson et al., 2006; Munschy et al., 2008). Briefly, PBDE analyses were conducted using approximately five grams of freeze-dried fish tissue. The freeze-dried fish tissue samples were spiked with recovery standards (BDE 
162139 and ${ }^{13} \mathrm{C}$ labelled BDE-209 - Wellington Laboratories Inc., Ontario, Canada-) prior to extraction, and then extracted with dichloromethane (DCM) using Accelerated Solvent Extraction (ASE, Dionex Corp., USA). The extracts were cleaned on a gel permeation chromatography glass column (460 $\mathrm{mm}$ x $26 \mathrm{~mm}$ ) filled with styrenedivinylbenzene (Bio-beads S-X3), eluted with DCM, fractionated on a silica and alumina column and treated with concentrated sulphuric acid followed by several rinses with iso-octane.

Total lipid content was systematically determined in duplicate in muscle ( $1 \mathrm{~g} \mathrm{ww})$ and liver (150 mg ww) according to the Folch et al. (1957) method, using dichloromethane instead of chloroform. The samples were homogenized and extracted in an excess of dichloromethane/methanol (2/1, v/v) solution and lipid content was determined gravimetrically.

\subsection{Instrumental analysis}

All fish tissue and spiked food samples were analysed for PBDEs using a Gas Chromatograph (Agilent 6890) coupled to a Mass Spectrometer (5973N) operated in electron capture negative ionisation (ECNI) mode. Detailed chromatographic conditions are given in Hong et al. (2009) and in the SI.

In order to confirm identification of PBDE congeners and to determine the number of bromine atoms of unidentified PBDEs, selected samples were also analysed by High Resolution Gas Chromatography - High Resolution Mass Spectrometry (HRGCHRMS). Instrumental details can be found in the SI. 
Samples were processed in the laboratory in a clean, low-dust atmosphere at positive pressure. Quality Assurance / Quality Control procedures were implemented for each batch of eight to ten samples, including procedural blanks, analysis of replicate samples, use of recovery surrogates in all samples, analysis of certified reference material and participation to intercomparison exercises.

Blank samples were analysed using glass powder, extracted and processed in the same manner as the fish samples. Blanks were contamination-free, with the exception of BDE-209, which was found at $2 \mathrm{pg} . \mu \mathrm{l}^{-1}$ injected (median value calculated on 17 blanks). BDE-209 limit of detection (LOD) was set at $8 \mathrm{pg} . \mu \mathrm{l}^{-1}$ injected, i.e., blank mean value plus 3 SDs. The LODs for other congeners were defined as 3 times the signal to noise

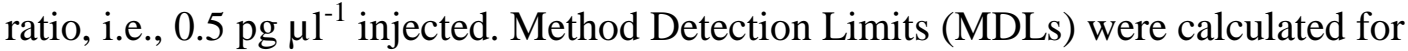
each sample taking into account the injection volume, the volume of the concentrated extract before injection and the extracted sample mass. They ranged from $0.001 \mathrm{ng} \mathrm{g}^{-1}$ ww to $0.06 \mathrm{ng} \mathrm{g}^{-1} \mathrm{ww}$ in fish tissues, and from $0.005 \mathrm{ng} \mathrm{g}^{-1}$ ww to $0.5 \mathrm{ng} \mathrm{g}^{-1}$ ww in food. High variations in BDE-209 levels in blanks were found between batches, with no obvious relation to the BDE-209 concentrations found in samples, hence ruling out cross-contamination problems. Therefore, BDE-209 concentrations were corrected from blank values in both exposed and control fish. The values obtained in each blank were used to correct the values in samples analysed in the same batch.

Replicate fish muscle $(n=7)$ and liver $(n=7)$ samples were analysed to evaluate our method accuracy in terms of repeatability, resulting in a relative standard deviation (RSD) in the $12-15 \%$ range in muscle samples and in the 9-20\% range in liver samples for all congeners except BDE-209, for which a higher RSD was observed (36\% and $32 \%$ in muscle and liver, respectively). 
210 Surrogate recoveries were $101 \pm 14 \%$ for BDE 139 and $91 \pm 16 \%$ for ${ }^{13} \mathrm{C}$ BDE 209

211 (mean \pm SD calculated on $\mathrm{n}=75$ analyses) and no surrogate correction was done for

212 the reported concentrations.

213 Certified reference material (WMF-01, supplied by Wellington laboratories Inc.,

214 Ontario, Canada) was routinely included in each sequence of samples and the results

215 were within certified values. WMF-01 consists of a freeze-dried fish sample for which

216 certified or indicative values are given for 7 congeners (namely, BDE-28, BDE-47,

217 BDE-99, BDE-100, BDE-153, BDE-154, BDE-183) at concentrations of between 0.53

$218 \pm 0.40 \mathrm{ng} \mathrm{g}^{-1}$ dry weight $(\mathrm{dw})$ and $123.2 \pm 24.8 \mathrm{ng} \mathrm{g}^{-1} \mathrm{dw}$. Recoveries were between 67

$219 \pm 23 \%$ and $117 \pm 9 \%$ (mean value \pm SD calculated on $\mathrm{n}=13$ replicate samples)

220 depending on the congener.

221 The laboratory regularly takes part in Quality Assurance of Information for Marine

222 Environmental Monitoring in Europe (QUASIMEME) intercomparison exercises for

223 PBDEs in biota and our Z-scores are satisfactory, i.e., between -2 and +2 .

224

225

226

227

\subsection{Data analysis}

Growth rates were calculated by fitting all fish weights to an exponential model over the exposure time:

Fish weight at $\mathrm{t}=\mathrm{a} \times \exp (\mathrm{b} \times \mathrm{t})$

whereby $\mathrm{a}$ is a constant, $\mathrm{b}$ is the growth rate in $\mathrm{g} \mathrm{day}{ }^{-1}$, and $\mathrm{t}$ the time in days (Martin et al., 2003).

In order to take into account the dilution of contaminant concentrations due to growth during the depuration phase, concentrations were corrected for growth rate by multiplying the concentrations by $[1+(\mathrm{b} \times \mathrm{t})]$ (Fisk et al., 1998). 
Depuration rate coefficients $\left(\mathrm{k}_{\mathrm{d}}\right)$ were calculated by fitting the data to a first-order decay

235

236

237 curve:

$$
\ln (\text { concentration })=a+\left(k_{d} \times t\right)
$$

whereby a is a constant, $\mathrm{k}_{\mathrm{d}}$ is the depuration rate coefficient and $\mathrm{t}$ is the exposure time (days) (Fisk et al., 1998).

Depuration half-lives were calculated on the exponential part of the depuration curve using:

$$
\mathrm{t}_{1 / 2}=\frac{\ln (2)}{\mathrm{kd}_{\mathrm{d}}}
$$

Apparent (i.e., net) AEs were calculated throughout the exposure period using the following equation (from Tomy et al., 2004):

$$
\operatorname{AE}(\%)=\frac{\left(\mathrm{C}_{\text {fish }}\right) \times(\text { fish body weight })}{\left(\mathrm{C}_{\text {food }}\right) \times(\text { cumulative mass of ingested feed })}
$$

where $C_{\text {fish }}\left(n g g^{-1}\right.$ ww) is the concentration in fish and $C_{\text {food }}\left(n g g^{-1}\right.$ ww) the concentration in food. PBDE concentrations in fish were calculated using the concentrations determined separately in liver and muscle, the fish liver weight and the fish muscle weight, which was estimated to be the whole body weight minus the liver weight. Remaining fish parts were not kept for contaminant analysis, and were therefore not taken into account for concentration calculations.

PBDE concentrations determined in fish tissues were not normalized to total lipid content, due to higher variations of these concentrations when normalized to lipid content.

\section{Results and Discussion}

\subsection{Fish health and growth parameters}


Fish health and growth parameters are presented in Table 2 up to day 168. Because of a smaller number of fish available for PBDE analysis at day 233 ( $n=16$ and $n=6$ for PBDE and solvent-control tanks, respectively), parameters are presented for fish maintained up to day 168 . Mortality was low throughout the experiment $(<2 \%$ of initial fish numbers) for all conditions (PBDE exposure, solvent-control and control tanks). No significant differences (Paired Student's t-test; $\mathrm{p}<0.05$ ) were observed in fish growth, liver somatic index and condition index between fish exposed to PBDE-spiked food and both control fish. Total lipid content in muscle and liver tissue was determined on each pooled sample and did not show any significant trends over the time period or in relation to exposure conditions. As experimental parameters for health were good and similar for all conditions throughout the experiment, the results of PBDE accumulation and depuration in fish obtained in all conditions could be compared all together. Fish growth obeyed an exponential kinetic law for PBDE-exposed fish and both control fish. However, fish growth rate calculated at day 233 was lower $\left(0.0058 \mathrm{~g} \mathrm{day}^{-1}\right)$ than fish growth rate calculated up to day $168\left(0.0076 \mathrm{~g} \mathrm{day}^{-1}\right)$. Contaminant concentrations were therefore corrected for growth using the two different growth rates.

\subsection{Bioaccumulation and depuration kinetic parameters}

Concentrations of PBDE congeners used to spike food were determined in control fish: they ranged from $0.003 \mathrm{ng} \mathrm{g}^{-1} \mathrm{ww}$ for BDE-153 to $0.093 \mathrm{ng} \mathrm{g}^{-1} \mathrm{ww}$ for BDE-47 (estimated in whole body). Since concentrations in control fish and solvent-control fish showed no significant difference (Paired Student's t-test; $p<0.05$ ), they were considered all together. All congeners administered in spiked food were detected in both the muscle and liver of exposed fish, at higher concentrations than in control fish (Fig. 
1). The highest concentrations were in the $2.8-10.6 \mathrm{ng} \mathrm{g}^{-1} \mathrm{ww}$ range for tri- to hexaBDEs, depending on the congeners, and $0.06 \mathrm{ng} \mathrm{g}^{-1} \mathrm{ww}$ for BDE-209. These maximum concentrations were generally observed at the end of the exposure period ( 84 days). Increased concentrations of all congeners were detected in the samples after 7 days of exposure, revealing a fast food uptake and assimilation. As shown in Fig. 1, linear PBDE accumulation kinetics were observed in fish during the exposure phase (3 months) followed by an exponential decrease during the depuration phase ( 5 months). Similar kinetics, contamination levels and standard deviations were observed for BDE47 and BDE-28 (data not shown). No steady-state was achieved for any congener during the 3-month exposure time. The observed depuration curves showed two-stage depuration kinetics, with a fast initial depuration up to day 112 (i.e., 28 days of depuration), followed by a slower depuration rate until the end of the experiment and reaching an apparent steady-state. At the later stage of the depuration phase, most congeners showed an increase of their concentrations. This may have been enhanced by the lower growth rate used at day 233 for correction of the concentrations. The uptake and depuration curves observed in this experiment were typical of those observed by other authors during bioaccumulation studies of hydrophobic contaminants in fish (Fisk et al., 1998; Tomy et al., 2004).

Assimilation, depuration rate constants and half-lives are presented in Table 3. Halflives ranged from 37 days for BDE-99 to 86 days for BDE-28. These values were slightly higher than those previously reported for juvenile carp (Cyprinus carpio) of initial body masses of 17-18 $\mathrm{g}$ exposed to food spiked at $100 \mathrm{ng} \mathrm{g}^{-1} \mathrm{ww}$ per PBDE congener (Stapleton et al., 2004a). In juvenile lake trout exposed to low-dose (1-3 ng g ${ }^{-1}$ dw) contaminated food, Tomy et al. (2004) reported half-lives of between 39 and 115 
days for the same congeners as in our experiment, while half-lives were higher for the same fish exposed at higher doses $\left(6-27 \mathrm{ng} \mathrm{g}^{-1} \mathrm{dw}\right)$, i.e., in the 26-346 days range. In our experiment, fish were exposed to higher doses, i.e., in the 100-200 $\mathrm{ng} \mathrm{g}^{-1} \mathrm{ww}$ range, but smaller fish (mean weights $17 \pm 5 \mathrm{~g}$ ) than in Tomy et al. (2004) experiment $(55 \pm 5 \mathrm{~g})$ were studied, which may lead to higher depuration rates and hence lower half-lives (Sijm and van der Linde, 1995; Fisk et al., 1998).

Apparent assimilation rates, estimated in whole fish body from concentrations determined in muscle and liver separately, were calculated using a linear regression relationship: they were in the $(3.1-12.4) \times 10^{-2} \mathrm{ng} \mathrm{g}^{-1}$ day $^{-1}$ range for tetra- to hexa-BDEs and much lower for BDE-209 (i.e., $0.08 \times 10^{-2} \mathrm{ng} \mathrm{g}^{-1}$ day $^{-1}$ ). Apparent depuration rates in whole body were in the $(0.81-1.85) \times 10^{-2} \mathrm{ng} \mathrm{g}^{-1}$ day $^{-1}$ range, hence of a similar order to those reported by Stapleton et al. (2004a) in juvenile carp and by Tomy et al. (2004) in juvenile lake trout. Previously published studies have shown that depuration rates and half-lives varied inversely with hydrophobicity, estimated with $\log \mathrm{K}_{\mathrm{ow}}$, with a maximum half-life for $\log \mathrm{K}_{\mathrm{ow}}$ of around 7 and slower depuration kinetics for highly hydrophobic compounds (Fisk et al., 1998, Stapleton et al., 2004a). In this study, no significant relationship was observed between calculated PBDE half-lives or depuration rates and $\log \mathrm{K}_{\mathrm{ow}}$, molecular weight or number of bromine atoms. This coincides with the results presented by Tomy et al. (2004). The absence of relationship observed in our study is probably due to the biotransformation of certain congeners. Generally speaking, debromination would enhance the depuration rates of metabolised congeners and lower the depuration rates of the subsequently-produced debrominated metabolites. Accumulation and depuration kinetics were also determined separately in muscle and liver. Interestingly, although the accumulation of all congeners followed a linear 
increase in muscle, some differences between congeners were noted in liver. BDE-28, BDE-47 and BDE-100 showed linear increases, whereas BDE-99 and BDE-153 showed a two-stage increase, with a rapid linear increase during the first two weeks of exposure, followed by a decrease in the accumulation rates (as illustrated for BDE-99 and BDE153 in Fig.2). After the first two weeks, BDE-99 accumulation rate nearly reached a steady-state. This would suggest an initial rapid assimilation of these two congeners in the liver, followed by a slow-down due to metabolism. BDE-99 and BDE-153 assimilation rates in liver were therefore estimated for both sections of the assimilation curve and showed much lower values after day 14 (Table 3). Assimilation rates in liver for all congeners were higher than those estimated in the whole body, especially for BDE-99 and BDE-153 during the first two weeks of exposure (Table 3). Antunes et al. (2008) reported higher assimilation rates for contaminants with high $\log \mathrm{K}_{\text {ow }}$ in liver than in muscle. Similar observations could be made in our experiment, as illustrated in Fig. 3 by the ratio of BDE-100 concentrations in liver versus those in muscle: this ratio increased sharply between day 0 and day 8 , then decreased until the end of the exposure time. Interestingly, this phenomenon was not observed for BDE-28 during the exposure time (Fig. 3), indicating that higher brominated congeners accumulate more easily in liver than lower brominated congeners. Depuration kinetics also showed some differences between the two tissues (see SI for illustration): while depuration started in muscle after day 91 (i.e., 7 days after the termination of the exposure), depuration in liver started immediately after exposure to PBDEs had ceased (i.e., after day 84). While in muscle, all congeners showed the same depuration curve, differences could be noticed in liver, in which the concentrations of the lower brominated congeners BDE-28 and BDE-47 showed no decrease during the depuration period, while other congeners 
exhibited a quick decrease between day 84 and day 91, followed by a stabilisation of the concentrations.

\subsection{Biotransformation of PBDE congeners in fish}

BDE-28, BDE-47 and BDE-100, administered at similar levels in food (circa $100 \mathrm{ng} \mathrm{g}^{-1}$ ww), were measured at similar levels in fish, whereas BDE-99, which was also present at circa $100 \mathrm{ng} \mathrm{g}^{-1} \mathrm{ww}$ in food, showed lower concentrations in fish (Fig. 1). This may be explained by a lower AE or by rapid transformation in fish. Some authors have shown that BDE-99 is either not assimilated, as in juvenile carp (Stapleton et al., 2004a), or degraded to lower brominated congeners, as in Chinook salmon (Onchorhynchus tshawytscha) and common carp (Stapleton et al., 2004c; Browne et al., 2009). Assimilation is partly controlled by passive diffusion and also by mediated uptake (Gobas et al., 1993; Burreau et al., 1997). Since passive diffusion is related to molecule physicochemical properties, BDE-99 and BDE-100 assimilation should be relatively similar. The lower assimilation observed for BDE-99 was hence probably due to its biotransformation in sole. BDE-153 was given at ca $200 \mathrm{ng} \mathrm{g}^{-1} \mathrm{ww}$ in food, but was present in fish tissues at similar levels to BDE-28, BDE-47 and BDE-100. BDE209 (200 $\mathrm{ng} \mathrm{g}^{-1} \mathrm{ww}$ in food) was detected at the lowest concentrations in exposed fish, and these concentrations were still higher than those determined in control fish (Fig.1). The lower concentrations observed for BDE-153 and BDE-209 in comparison to exposure levels may be due to a combined effect of physicochemical properties (higher molecular weight, $\log \mathrm{K}_{\mathrm{ow}}$, number of bromine atoms) and biotransformation. This issue will be further discussed below. 
Moreover, certain PBDE congeners not added to the spiked food were detected throughout the whole study period in fish exposed to spiked food. They include two tetra-brominated congeners (BDE-49 and one unidentified -Tetra-1), one pentabrominated congener (Penta-1), the hexa-brominated BDE-154, two hepta-brominated congeners (BDE-183, Hepta-1), and the octa-brominated BDE-202. These congeners were present in exposed fish at higher concentrations than in control fish (Fig. 1); the concentrations of BDE-183, Hepta-1 and BDE-202 were below the MDL (i.e., $<0.001$ $\mathrm{ng} \mathrm{g}^{-1} \mathrm{ww}$ ), while BDE-49, Tetra-1, Penta-1, and BDE-154 concentrations ranged from $0.003 \mathrm{ng} \mathrm{g}^{-1} \mathrm{ww}$ for Tetra-1 and Penta-1 to $0.03 \mathrm{ng} \mathrm{g}^{-1} \mathrm{ww}$ for BDE-49. Identification of these congeners was confirmed by High Resolution Mass Spectrometry (HRMS). Since congeners Tetra-1, Penta-1, Hepta-1 could not be identified against authentic standards, they were quantified relative to BDE-49, BDE-100 and BDE-183 calibration curves, respectively. BDE-202, which was not present in the calibration solution used for quantification by GC/ECNI-MS, was quantified relative to BDE-183.

In order to check if these additional congeners were the result of accumulation from food or from metabolism in fish, theoretical concentrations in fish after 84 days of exposure were calculated. In order to do so, we considered the concentration determined in spiked food, or the MDL (i.e., $0.5 \mathrm{ng} \mathrm{g}^{-1} \mathrm{ww}$, see Table 1) for congeners < MDL, the total biomass of fish at day 84 , and the total mass of food given to the fish up to day 84 . Theoretical concentrations were corrected for the variation of AEs with $\log \mathrm{K}_{\mathrm{ow}}$, using the relationship estimated in this study (see paragraph 3.5).

BDE-154 was initially present in non-spiked food, at $0.043 \mathrm{ng} \mathrm{g}^{-1} \mathrm{ww}$, and was determined in spiked food at a higher level $\left(1 \mathrm{ng} \mathrm{g}^{-1} \mathrm{ww}\right.$, Table 1$)$. This was most probably explained by the presence of BDE-154 identified in BDE-99 solution used to 
spike food, at a level of circa $1 \%$ of BDE-99, which would give a theoretical concentration in spiked food of around $1.5 \mathrm{ng} \mathrm{g}^{-1}$ ww. BDE-154 theoretical concentration calculated in fish after 84 days of exposure to spiked food would be circa $0.08 \mathrm{ng} \mathrm{g}^{-1} \mathrm{ww}$, which is close to the concentration determined at that time $\left(0.13 \mathrm{ng} \mathrm{g}^{-1}\right.$ ww). BDE-183 was detected in spiked food at $1.5 \mathrm{ng} \mathrm{g}^{-1} \mathrm{ww}$, while it was not detected (i.e., $<0.005 \mathrm{ng} \mathrm{g}^{-1} \mathrm{ww}$ ) in non-spiked food. Its presence in spiked food is likely due to impurity in BDE-153 spiking solution (at circa 1\% of BDE-153). BDE-183 theoretical concentration in fish after 84 days would be circa $0.08 \mathrm{ng} \mathrm{g}^{-1} \mathrm{ww}$, while the measured concentration at day 84 was $0.06 \mathrm{ng} \mathrm{g}^{-1}$ ww. Hence, BDE-154 and BDE-183 identified in fish fed spiked food resulted more probably from direct accumulation from food than from metabolism in fish. The same calculations were done for the other congeners (BDE-49, Tetra-1, Penta-1, Hepta-1 et BDE-202), showing that they were originating from metabolism in fish, as discussed below.

The congeners originating from parent PBDE debromination showed similar increasing and decreasing profiles over time to the congeners given in food (Fig. 1). Their accumulation rates -or "bioformation" rates-, depuration rates and half-lives are presented in Table 4. Most exhibited lower accumulation rates than the parent congeners, while their depuration rates, estimated in the whole fish body, were of the same order of magnitude as those of the parent congeners. The increase in concentrations at day 233, which was observed for most parent PBDEs, was also observed for the debrominated congeners, especially for Tetra-1, Penta-1 and Hepta-1.

\subsection{Debromination pathways}


During our experiment, although fish were exposed to a mix of PBDEs and not to single congeners, an attempt was made to explain the presence of the congeners thought to originate from the debromination of parent PBDEs.

Debromination of BDE-99 has already been shown in different fish species, although with different debromination pathways. For example, Chinook salmon debrominated BDE-99 into BDE-49, while common carp preferentially debrominated BDE-99 into BDE-47 (Stapleton et al., 2004a; Benedict et al., 2007; Browne et al., 2009). In our experiment, it is not unreasonable to assume that BDE-49 may originate from BDE-99. However, debromination of BDE-153 into BDE-49 cannot be absolutely dismissed. Further experiments during which fish would be exposed to only BDE-153 should be conducted in order to verify this assumption. BDE-49 shows much higher levels in exposed fish versus control fish (Fig.1). BDE-49 was present initially in non-spiked food at $0.18 \mathrm{ng} \mathrm{g}^{-1} \mathrm{ww}$, and, due to a higher MDL, was not detected in spiked food (Table 1). Using the calculation explained above, BDE-49 concentration in fish after 3 months of exposure to food would be $0.05 \mathrm{ng} \mathrm{g}^{-1} \mathrm{ww}$, hence far lower than the concentration determined at day $84\left(3.7 \mathrm{ng} \mathrm{g}^{-1} \mathrm{ww}\right)$ in exposed fish. BDE-49 was present at similar levels to BDE-99 in fish during the contamination phase and was even higher during the depuration phase, which would indicate a high debromination rate of BDE-99 to BDE-49.

Tetra-1 was determined in exposed fish at $0.5 \mathrm{ng} \mathrm{g}^{-1} \mathrm{ww}$ at day 84 (Fig. 1). This level could not result from the accumulation from food, as Tetra- 1 was below the MDL in both non-spiked and spiked food (theoretical concentration in fish after 84 days of exposure would be $0.05 \mathrm{ng} \mathrm{g}^{-1} \mathrm{ww}$ ). The origin of Tetra- 1 remains uncertain: it could originate from the direct loss of one bromine atom of one of the congeners given in 
food, or from successive and staggered debrominations from higher-brominated congeners.

Previously-published studies have reported BDE-209 debromination into lower brominated congeners - mainly hexa- to nona-BDEs - in juvenile carp and rainbow trout (Oncorhynchus mykiss) (Kierkegaard et al., 1999; Stapleton et al., 2004c; Tomy et al., 2004; Stapleton et al., 2006). In our experiment, several PBDEs could originate from BDE-209.

The Penta-1 congener was detected in all samples at concentrations of up to $2.5 \mathrm{ng} \mathrm{g}^{-1}$ ww at the end of the exposure time. Similarly to BDE-49, Penta-1 was identified in nonspiked food, at $0.022 \mathrm{ng} \mathrm{g}^{-1} \mathrm{ww}$, and was below the MDL in spiked food (Table 1). The theoretical concentration in fish at the end of the exposure period would be $0.04 \mathrm{ng} \mathrm{g}^{-1}$ ww, while Penta- 1 was determined at $2.5 \mathrm{ng} \mathrm{g}^{-1} \mathrm{ww}$ in the exposed fish at day 84 . We can thus hypothesize that Penta-1 results from debromination in fish. BDE-209 could be a potential parent congener, although BDE-153 debromination could not be completely ruled out. Exposure of juvenile carp (Cyprinus carpio) to BDE-209 lead to the formation of one penta-brominated metabolite, and to similar congener profiles as those observed during our experiment (Stapleton et al., 2004c). Thus, in sole, Penta-1 could also originate from BDE-209. However, in our experiment, Penta-1 was determined at fairly high concentrations (up to $2.5 \mathrm{ng} \mathrm{g}^{-1} \mathrm{ww}$ at day 84), which would therefore imply a high assimilation of BDE-209. Exposure to BDE-153 or BDE-209, individually, would be necessary to confirm the origin of Penta-1 in sole.

Hepta-1 and BDE-202 theoretical concentrations were both estimated in exposed fish at day 84 as $0.03 \mathrm{ng} \mathrm{g}^{-1} \mathrm{ww}$ and $0.02 \mathrm{ng} \mathrm{g}^{-1} \mathrm{ww}$, respectively. Their concentrations determined in exposed fish at day 84 were $0.17 \mathrm{ng} \mathrm{g}^{-1} \mathrm{ww}$ and $0.07 \mathrm{ng} \mathrm{g}^{-1} \mathrm{ww}$, 
respectively. We can then reasonably assume that both congeners originated mostly from BDE-209 debromination in fish. (Hepta-1 + BDE-202) / BDE-209 ratio showed an increase during the exposure period, followed by a stabilization during the depuration phase (Fig. 4). This ratio exhibited a higher value at day 233, in relation to the increase of Hepta- 1 concentration observed at that time, and a higher variability, mostly due to low-level concentrations of BDE-209.

Information on the pathways and mechanisms of in vivo debromination in fish is still scarce, although, as previously suggested by Stapleton et al. (2004c), one could assume that PBDE debromination occurs via the removal of one bromine atom at a time. Deiodinase enzymes - which regulate thyroid hormones- and the cytochrome P450 system may play a role in PBDE debromination in fish (Burreau et al., 2000, Tomy et al., 2004; Benedict et al., 2007). Preferential removal of meta-substituted bromines suggests that deiodinase enzyme systems may play a role in debromination (Stapleton et al., 2004c). In our study, the hypothesized debromination pathways presented above would suggest that debromination occurred via the removal of a $\mathrm{Br}$ atom in the para position, i.e., during BDE-99 transformation into BDE-49 and during BDE-209 transformation into BDE-202.

\subsection{Assimilation efficiencies (AEs)}

The apparent AEs of BDE-28, BDE-47, BDE-99, BDE-100 and BDE-153 were, on average throughout the exposure time, in the 10-16\% range, whereas BDE-209 showed a lower value, i.e., $1.4 \%$ (Table 3). To take into account the biotransformation of BDE99 and BDE-209, and in accordance with the above discussion on hypothesized debromination routes, these AEs were calculated in relation to the summed 
concentrations of BDE-99 + BDE-49, and BDE-209 + Hepta-1 + BDE-202, respectively. They may very well be underestimated, as not all the debrominated metabolites were taken into account for the calculation. Hydroxylated metabolites were shown to be negligible (Munschy et al., 2010) and hence have not been considered for the estimation of AEs. On the other hand, AEs may be overestimated if some of the congeners to which fish were initially exposed through diet were also produced via debromination processes. However, the AEs calculated in this study did not show any increase throughout the exposure period for most congeners; if this had been the case, debromination of congeners into the ones to which the fish were exposed via spiked food could have occurred. Only the AEs calculated for BDE-209 showed an increase during the exposure time, varying from $0.4 \%$ at day 8 to $2.6 \%$ at day 84 . Since BDE209 have no precursor, and showed no increase in spiked food over time, this could be explained by the increase of Hepta-1 concentration relative to BDE-209 concentration with time (Fig. 1).

Unlike previously observed by various authors (Burreau et al., 1997; Stapleton et al., 2004a; Tomy et al., 2004), the AEs calculated in this study showed an inverse linear relationship with $\log \mathrm{K}_{\mathrm{ow}}$ (Fig. 5), molecular weight and number of bromine atoms (not shown). Their values differed from those previously reported in the literature. Burreau et al. (1997) reported AEs of 90\%, 60\% and 40\% for BDE-47, BDE-99 and BDE-153, respectively, in pike (Esox lucius). Stapleton et al. (2004a) found AEs of 20\%, 93\% and 4\% for BDE-28, BDE-47 and BDE-153, respectively, in common carp, whereas BDE99 was not assimilated at all. Tomy et al. (2004) reported AEs ranging from $31 \%$ for BDE-99 to 53\% for BDE-28 in juvenile lake trout. BDE-209 was systematically found 
to have lower AEs, ranging from less than 1\% (Kierkegaard et al., 1999) to 5.2\% (Tomy et al., 2004).

Estimation of AEs depends on numerous factors related to exposure parameters, such as contaminant levels in food and food quality. AEs calculated by Tomy et al. (2004) were generally lower when fish were exposed to low doses rather than high doses. Food lipid content is another parameter which may influence AEs, although the way in which this parameter influences efficiency is a matter of controversy (Burreau et al., 1997; Fisk et al., 1998; Gobas et al., 1993).

Additionally, AEs are influenced by the calculation method used to estimate whole body concentrations. While our calculations were based on concentrations determined separately in muscle and liver (as per Kierkegaard et al., 1999), other authors used either whole body (with emptied stomach cavity) and liver separately (Stapleton et al., 2004a), whole body minus the gastrointestinal tract (Burreau et al., 1997), or whole body minus liver and gastrointestinal tract (Tomy et al., 2004). Calculating whole fish body concentrations on the basis of concentrations determined separately in liver and muscle may lead to an underestimation of whole body contamination, especially if contaminants are stored in significant amounts in tissues not taken into account for the calculation, and if these tissues represent a significant mass versus fish body weight. Among the fish parts which had not been analysed in our study, and which may represent a significant accumulation compartment, is the tissue surrounding the fins. Observations conducted on dorsal and ventral fins under a microscope revealed lipid accumulation at the base of the fins in juvenile sole (personal communication). Boon et al. (1984) have shown that, in addition to the liver, gut, skin, carcass and interparietal fat may accumulate significant amounts of organic contaminants in sole. Our AEs may 
therefore have been underestimated, mainly because they were calculated on the basis of contaminant concentrations in liver and muscle only. This underestimation may nevertheless be limited in view of the short exposure time in our experiment. The extent of contaminant accumulation in tissues other than muscle and liver is related to accumulation kinetics, which differ according to tissue type (Gobas et al., 1999). The relative contribution of various tissues to whole body PBDE concentrations over time in sole will be examined in more detail in the future.

\section{Conclusions}

The results obtained in our study demonstrated that juvenile sole accumulate PBDEs from diet in a linear manner, and that this accumulation is followed by an exponential decrease after exposure to PBDEs through diet has ceased. Apparent assimilation rates in fish were influenced by PBDE debromination, and showed different values in liver, compared to those estimated in whole body. The results also showed that juvenile sole have the ability to bio-transform certain PBDEs into debrominated congeners. The main debrominated metabolities found during this study were BDE-49 and an unknown pentabrominated congener; other tetra-brominated to octa-brominated congeners were also detected, at lower concentrations. In common sole, BDE-99 debromination may preferentially yield BDE-49, although BDE-49 could also originate from BDE-153 debromination. Sole was shown to assimilate BDE-209 and noticeably metabolise it into a series of lower brominated congeners. The hypothesized debromination pathways mainly involved the removal of one $\mathrm{Br}$ atom in the para position. AEs were influenced by PBDE transformation in fish and were inversely correlated with $\log \mathrm{K}_{\mathrm{ow}}$. 
566 This research was funded by the "Agence Nationale pour la Recherche" in the

567 framework of the "Vulnérabilité Milieux et Climat" project (ANR-06-PVULN-013).

568 The authors would like to thank all the technical staff for their assistance in the

569 experimental work and fish maintenance. Eric Durieux and Véronique Loizeau from

570 Ifremer are gratefully acknowledged for their fruitful discussion on lipid distribution

571 and PCB accumulation in fish, respectively. Laura Valentine from "English Assistance

572 for Industry" is acknowledged for the English corrections made to the manuscript. We

573 would also like to thank the anonymous reviewers for their assistance in this

574 manuscript. 


\section{References}

Antunes, P., Hendriks, A.J., Huijbregts, M.A.J., Gil, O., Reis-Henriques, M.A., 2008. Organ-specific accumulation and elimination patterns of PCBs in adult seabass (Dicentrarchus labrax). Science of the Total Environment 407, 204-210.

Benedict, R.T., Stapleton, H.M., Letcher, R.J., Mitchelmore, C.L., 2007. Debromination of polybrominated diphenyl ether-99 (BDE-99) in carp (Cyprinus carpio) microflora and microsomes. Chemosphere 69, 987-993.

Boon, J.P., Oudejans, R.C.H.M., Duinker, J.C., 1984. Kinetics of individual polychlorinated biphenyl (PCB) components in juvenile sole (Solea solea) in relation to their concentrations in food and to lipid metabolism. Comparative Biochemistry and Physiology 79C, 131-142.

Browne, E.P., Stapleton, H.M., Kelly, S.M., Tilton, S.C., Gallagher, E.P., 2009. In vitro hepatic metabolism of 2,2',4,4',5-pentabromodiphenyl ether (BDE-99) in Chinook salmon (Onchorhynchus tshawytscha). Aquatic toxicology 92, 281-287.

BSEF, 2010. Bromine Science and Environmental Forum, www.bsef.com

Burreau, S., Axelman, J., Broman, D., Jakobsson, E., 1997. Dietary uptake in pike (Esox lucius) of some polychlorinated biphenyls, polychlorinated naphthalenes and polybrominated diphenyl ethers administered in natural diet. Environmental Toxicology and Chemistry 16, 2508-2513.

Burreau, S., Broman, D., Orn, U., 2000. Tissue distribution of 2,2’24,4'tetrabromo $\left[{ }^{14} \mathrm{C}\right]$ diphenyl ether $\left(\left[{ }^{14} \mathrm{C}\right]-\mathrm{PBDE}-47\right)$ in pike (Esox lucius) after dietary exposure - a time series study using whole body autoradiography. Chemosphere 40, 977-985. 
Coutteau, P., Robles, R., Spruyt, W., 2001. Ongrowing feed for Senegal sole (Solea senegalensis Kaup). In: Abstracts of Contribution Presented at the International Conference Aquaculture Europe 2001. Special Publication no. 29. European Aquaculture Society, pp. 58-59.

Darnerud, P-O., Eriksen, G.S., Jóhannesson, T., Larsen, P.B., Viluksela, M., 2001. Polybrominated Diphenyl Ethers: Occurrence, Dietary Exposure, and Toxicology. Environ Health Perspectives 109 (suppl. 1), 49-68.

Decision 2455/2001/EC of 20 November 2001 establishing a list of priority substances in the field of water policy, Official Journal of the European Communities L 331, 15.12.2001, 1 .

de Wit, C.A., 2002. An overview of brominated flame retardants in the environment. Chemosphere 46, 583-624.

Directive 2003/11/EC of the European Parliament and of the Council of 6 February 2003. Official Journal of the European Union, L42/45-46.

Fisk, A.T., Norstrom, R.J., Cymbalisty, C.D., Muir, D.C.G., 1998. Dietary accumulation and depuration of hydrophobic organochlorines: bioaccumulation parameters and their relationship with the octanol/water partition coefficient. Environmental Toxicology and Chemistry 17, 951-961.

Folch, J., M. Lees, M., Sloane-Stanley, G.H., 1957. A simple method for the isolation and purification of total lipids from animal tissues. The Journal of Biological Chemistry 226, 497-509. 
619 Gobas, F.A.P.C., McCorquodale, J.R., Haffner, G.D., 1993. Intestinal absorption and 620 biomagnification of organochlorines. Environmental Toxicology and Chemistry 12, $621 \quad 567-576$.

Gobas, F.A.P.C., Wilcokson, J.B., Russell, R.W., Haffner, G.D., 1999. Mechanism of biomagnification in fish under laboratory and field conditions. Environmental Science and Technology 33, 133-141.

Hites, R.A., 2004. Polybrominated diphenyl ethers in the environment and in people: a meta-analysis of concentrations. Environmental Science and Technology 38, 945956.

Hong, S. H., Munschy, C., Kannan, N., Tixier, C.,Tronczynski, J., Héas-Moisan, K., Shim, W.J., 2009. PCDD/F, PBDE, and nonylphenol contamination in a semienclosed bay (Masan Bay, South Korea) and a Mediterranean lagoon (Thau, France). Chemosphere 77, 854-862.

Johansson, I., Moisan, K., Guiot, N., Truquet, I., Munschy, C., Tronczyński, J., 2006. Polybrominated diphenyl ethers (PBDEs) in mussels from selected French coastal sites: 1981-2003. Chemosphere 64, 296-305.

Kelly, B.C., Ikonomou, M.G., Blair, J.D., Gobas, F.A.P.C., 2008. Hydroxylated and methoxylated polybrominated diphenyl ethers in a Canadian Arctic marine food web. Environmental Science and Technology 42, 7069-7077.

Kierkegaard, A., Balk, L, Tjärnlund, U., De Wit, C., Jansson, B., 1999. Dietary uptake and biological effects of decabromodiphenyl ether in rainbow trout (Oncorhynchus mykiss). Environmental Science and Technology 33, 1612-1617. 
Law, R.L.J., Alaee, M., Allchin, C.R., Boon, J.P., Lebeuf, M., Lepom, P., Stern, G.A., 2003. Levels and trends of polybrominated diphenylethers and other brominated flame retardants in wildlife. Environment International 29, 757-770.

Law, R.J., Allchin, C.R., de Boer, J., Covaci, A., Herzke, D., Lepom, P., Morris, S., Tronczynski, J., de Wit, C., 2006. Levels and Trends of Brominated Flame Retardants in the European Environment. Chemosphere 64, 187-208.

Legler, J., 2008. New insights into the endocrine disrupting effects of brominated flame retardants. Chemosphere 73, 216-222.

Martin, J.W., Mabury, S.A., Solomon, K.R., Muir, D.C.G., 2003. Dietary accumulation of perfluorinated acids in juvenile rainbow trout (Oncorhynchus mykiss). Environmental Toxicology and Chemistry 22, 189-195.

Munschy, C., Guiot, N., Héas-Moisan, K., Tixier, Tronczyński, C., 2008. Polychlorinated dibenzo-p-dioxins and dibenzofurans (PCDD/Fs) in marine mussels from French coasts: Levels, patterns and temporal trends from 1981 to 2005. Chemosphere, 73(6), 945-953.

Munschy, C., Héas-Moisan, K., Tixier, C.,. Pacepavicius, G., Alaee, M., 2010. Dietary exposure of juvenile common sole (Solea solea L.) to polybrominated diphenyl ethers (PBDEs): Part 2. Formation, bioaccumulation and elimination of hydroxylated metabolites. Environmental Pollution 158, 3527-3533.

Nicolas, D., Le Loc’h, F., Désaunay, Y., Hamon, D., Blanchet, A., Le Pape, O., 2007. Relationships between benthic macrofauna and habitat suitability for juvenile common sole (Solea solea, L.) in the Vilaine estuary (Bay of Biscay, France) nursery ground. Estuarine, Coastal and Shelf Science 73, 639-650. 
Riou, P., Le Pape, O., Rogers, S.I., 2001. Relatoive contributions of different sole and plaice nurseries to the adult population in the Eastern Channel: application of a combined method using generalized linear models and a geographic information system. Aquatic Living Resources 14, 125-135.

Ross, P.S., Couillard, C.M., Ikonomou, M.G., Johannessen, S.C., Lebeuf, M., Macdonald, R.W., Tomy, G.T., 2009. Large and growing environmental reservoirs of Deca-BDE present an emerging health risk for fish and marine mammals. Marine Pollution Bulletin 58, 7-10.

Schram, E., Van der Heul, J.W., Kamstra, A., Verdegem, M.C.J, 2006. Stocking density-dependent growth of Dover sole (Solea solea). Aquaculture 252, 339-347.

Shaw, S.D., Kannan, K., 2009. Polybrominated diphenyl ethers in marine ecosystems of the American continents : foresight from current knowledge. Reviews on Environmental Health 24, 157-229.

Sijm, D.T.H.M., van der Linde, A., 1995. Size-dependent bioconcentration kinetics of hydrophobic organic chemicals in fish based on diffusive mass transfer and allometric relationships. Environmental Science and Technology 29, 2769-2777.

Stapleton, H.M., Letcher, R.J., Li, J., Baker, J.E., 2004a. Dietary accumulation and metabolism of polybrominated diphenyl ethers by juvenile carp (Cyprinus carpio). Environmental Toxicology and Chemistry 23, 1939-1946.

Stapleton, H.M., Letcher, R.J., Baker, J.E.., 2004b. Debromination of polybrominated diphenyl ether congeners BDE 99 and BDE 183 in the intestinal tract of the common carp (Cyprinus carpio). Environmental Science and Technology 38, 1054-1061. 
Stapleton, H.M., Alaee, M., Letcher, R.J., Baker, J.E., 2004c. Debromination of the flame retardant decabromodiphenyl ether by juvenile carp (Cyprinus carpio) following dietary exposure. Environmental Science and Technology 38, 112-119.

Stapleton, H.M., Brazil, B., Holbrook, R.D., Mitchelmore, C.L., Benedict, R., Konstantinov, A., Potter, D., 2006. In vivo and in vitro debromination of decabromodiphenyl ether (BDE 209) by juvenile rainbow trout and common carp. Environmental Science and Technology 40, 4653-4658.

Tanabe, S., Ramu, K., Isobe, T., Takahashi, S., 2008. Brominated flame retardants in the environment of Asia-Pacific: an overview of spatial and temporal trends. Journal of Environmental Monitoring, 10, 188-197.

Tomy, G.T., Palace, V.P., Halldorson, T, Braekevelt, E, Danell, R, Wautier, K, Evans, B, Brinkworth, L, Fisk, A.T., 2004. Bioaccumulation, biotransformation and biochemical effects of brominated diphenyl ethers in juvenile lake trout (Salvelinus namaycush). Environmental Science and Technology 38, 1496-1504.

Ward, J., Mohapatra, S.P., Mitchell, A., 2008. An overview of policies for managing polybrominated diphenyl ethers (PBDEs) in the Great Lakes basin. Environment International 34, 1148-1156. 
Figure 1

Accumulation and depuration of PBDEs in common sole exposed to PBDEs through diet. Concentrations are expressed in $\mathrm{ng} \mathrm{g}^{-1} \mathrm{ww}$ in whole body. Mean concentrations and standard deviations were calculated and are shown when replicate pooled samples were analysed. In most control fish samples, standard deviations are low and hence do not appear on the figures. Concentrations of Hepta-1 and BDE-202 in control fish are below the MDL.

\section{Figure 2}

BDE-99 and BDE-153 concentrations ( $\mathrm{ng} \mathrm{g}^{-1} \mathrm{ww}$ ) in the liver of PBDE-exposed sole during the exposure period.

\section{Figure 3}

Ratio of PBDE concentrations in liver ( $\left.\mathrm{ng} \mathrm{g}^{-1} \mathrm{ww}\right)$ versus PBDE concentrations in muscle ( $\left.\mathrm{ng} \mathrm{g}^{-1} \mathrm{ww}\right)$ for BDE-28 and BDE-100.

\section{Figure 4}

(Hepta-1 + BDE-202) / BDE-209 ratios during the 3-month exposure period and the 5month depuration period.

\section{Figure 5}

Assimilation efficiencies (\%) of the six PBDEs given in food at $\mathrm{t}=84$ days in common sole. $\log \mathrm{K}_{\mathrm{ow}}$ values are those of Kelly et al. (2008). 


\section{Table 1}

PBDE concentrations ( $\mathrm{ng} \mathrm{g}^{-1} \mathrm{ww}$ ) in non-spiked and spiked food

\begin{tabular}{lcc}
\hline Congener & $\begin{array}{c}\text { Concentration in } \\
\text { non-spiked food }^{\mathrm{a}}\end{array}$ & $\begin{array}{c}\text { Concentrations in } \\
\text { spiked food }^{\mathrm{b}}\end{array}$ \\
\hline BDE-28 & $0.028 \pm 0.004$ & $84.8 \pm 4.4$ \\
BDE-47 & $0.390 \pm 0.046$ & $82.2 \pm 4.5$ \\
BDE-49 & $0.165 \pm 0.012$ & $<0.5$ \\
Tetra-1 & $<0.005$ & $<0.5$ \\
BDE-99 & $0.093 \pm 0.008$ & $85.7 \pm 5.2$ \\
Penta-1 & $0.022 \pm 0.0002$ & $<0.5$ \\
BDE-100 & $0.116 \pm 0.011$ & $93.1 \pm 6.4$ \\
BDE-153 & $0.015 \pm 0.001$ & $181.1 \pm 15.7$ \\
BDE-154 & $0.043 \pm 0.003$ & $1.0 \pm 0.5$ \\
BDE-183 & $<0.005$ & $1.5 \pm 0.3$ \\
Hepta-1 & $<0.005$ & $<0.5$ \\
BDE 202 & $<0.005$ & $<0.5$ \\
BDE-209 & $0.083 \pm 0.008$ & $184.2 \pm 23.0$
\end{tabular}

732

${ }^{a}$ mean concentration \pm standard deviation determined on 4 replicates of non-spiked commercial food

${ }^{\mathrm{b}}$ mean concentration \pm standard deviation determined on a total of 20 replicates from the various batches of spiked food 
Table 2

Health and growth parameters monitored in exposed and control fish during an 8-month fish exposure experiment

\begin{tabular}{|c|c|c|c|c|}
\hline & & $\begin{array}{c}\text { PBDE } \\
\text { exposed fish }\end{array}$ & $\begin{array}{c}\text { Solvent-control } \\
\text { fish }\end{array}$ & $\begin{array}{l}\text { Control } \\
\text { fish }\end{array}$ \\
\hline Number of fish & $\begin{array}{l}\text { t } 0 \\
\text { t } 168\end{array}$ & $\begin{array}{c}470 \\
37\end{array}$ & $\begin{array}{c}492 \\
14\end{array}$ & $\begin{array}{c}474 \\
64\end{array}$ \\
\hline $\begin{array}{l}\text { Mortality (total during } \\
\text { experiment) }\end{array}$ & & 9 & 4 & 7 \\
\hline Fish mass $(\mathrm{g})^{\text {a }}$ & $\begin{array}{l}\text { t } 0 \\
\text { t } 168\end{array}$ & $\begin{array}{c}17.4 \pm 5.4 \\
61.3 \pm 20.6\end{array}$ & $\begin{array}{l}17.4 \pm 5.4 \\
63.3 \pm 17.5\end{array}$ & $\begin{array}{c}17.4 \pm 5.4 \\
57.5 \pm 23.1\end{array}$ \\
\hline Growth rate $\left(10^{-3} / \mathrm{d}\right)^{\mathrm{a}, \mathrm{b}}$ & Whole fish & $7.6 \pm 0.3$ & $7.7 \pm 0.4$ & $7.4 \pm 0.4$ \\
\hline Lipids $(\%) \mathrm{ww}^{\mathrm{c}}$ & $\begin{array}{l}\text { Muscle } \\
\text { Liver }\end{array}$ & $\begin{array}{l}2.0 \pm 0.5 \\
8.8 \pm 1.5\end{array}$ & $\begin{array}{l}2.0 \quad 0.5 \\
7.5 \pm 1.5\end{array}$ & $\begin{array}{l}1.8 \pm 0.3 \\
7.1 \pm 1.0\end{array}$ \\
\hline $\operatorname{LSI}(\%)^{\mathrm{c}, \mathrm{d}}$ & & $1.01 \pm 0.28$ & $1.02 \pm 0.31$ & $1.00 \pm 0.30$ \\
\hline Condition index $(\%)^{\mathrm{c}, \mathrm{e}}$ & & $0.97 \pm 0.15$ & $0.97 \pm 0.14$ & $0.96 \pm 0.12$ \\
\hline
\end{tabular}

${ }^{a}$ Fish mass and growth rates were calculated from fish sampled for PBDE analysis

${ }^{\mathrm{b}}$ Growth rates were calculated from: weight $=\mathrm{a} \times \exp (\mathrm{b} \times$ time $)$, whereby $\mathrm{b}$ is the growth rate

${ }^{\mathrm{c}}$ mean value \pm standard deviation calculated throughout the experiment

${ }^{\mathrm{d}}$ LSI: $($ liver somatic index $)=($ mass liver ww $/$ mass whole body $\mathrm{ww}) \times 100$

${ }^{\mathrm{e}}$ Condition index $=\left(\right.$ weight $(\mathrm{g}) /$ length $\left.^{3}(\mathrm{~cm})\right) \times 100$ 
Table 3

Bioaccumulation and elimination parameters of selected PBDE congeners using artificiallycontaminated food during an 8-month fish exposure experiment

\begin{tabular}{lccccc}
\hline Congener & $\begin{array}{c}\text { Assimilation rate } \\
\text { (whole body) } \\
10^{-2} \text { ng/g/day }\end{array}$ & $\begin{array}{c}\text { Assimilation rate } \\
\text { (liver) } \\
10^{-2} \text { ng/g/day }\end{array}$ & $\begin{array}{c}\text { Depuration rate } \\
\text { (whole body) } \\
10^{-2} \mathrm{ng} / \mathrm{g} / \mathrm{day}\end{array}$ & $\begin{array}{c}\text { Half-life } \\
\text { days }\end{array}$ & $\begin{array}{c}\text { Assimilation } \\
\text { Efficiency }^{\mathrm{d}}\end{array}$ \\
\hline BDE-28 & $11.3 \pm 0.7$ & $41.2 \pm 1.4$ & $0.81 \pm 0.25$ & $86 \pm 27$ & $16.1 \pm 5.3$ \\
BDE-47 & $10.3 \pm 0.6$ & $42.1 \pm 2.4$ & $1.18 \pm 0.41$ & $59 \pm 21$ & $15.4 \pm 5.0$ \\
BDE-99 & $3.1 \pm 0.4$ & $50.9 \pm 4.0^{\mathrm{a}}$ & $1.85 \pm 0.35$ & $37 \pm 7$ & $13.2 \pm 4.1$ \\
& & $2.2 \pm 1.5^{\mathrm{a}}$ & & & \\
BDE-100 & $10.8 \pm 0.6$ & $58.3 \pm 6.7$ & $1.11 \pm 0.44$ & $62 \pm 24$ & $13.8 \pm 4.7$ \\
BDE-153 & $12.4 \pm 1.0$ & $300.7 \pm 46.9^{\mathrm{a}}$ & $0.83 \pm 0.33$ & $83 \pm 33$ & $10.1 \pm 4.1$ \\
& & $41.6 \pm 12.3^{\mathrm{a}}$ & & & \\
BDE-209 & $0.08 \pm 0.03^{\mathrm{b}}$ & $3.1 \pm 0.8^{\mathrm{b}}$ & $1.62 \pm 0.30$ & $43 \pm 8$ & $1.4 \pm 0.9$
\end{tabular}

${ }^{a}$ BDE-99 and BDE-153 assimilation rates in liver were calculated for both parts of the assimilation curve (see discussion in 3.2 and Fig. 2).

${ }^{\mathrm{b}}$ BDE-209 assimilation rates (whole-body and liver) were calculated from concentrations determined up to day 56 (linear section of the assimilation curve).

${ }^{\mathrm{c}}$ Depuration rates were calculated using the exponential part of the curve

$759{ }^{\mathrm{d}}$ Assimilation efficiencies are mean values ( \pm standard deviation) calculated throughout the exposure time 
Table 4

Bioaccumulation and elimination parameters of debrominated metabolites of PBDE congeners during an 8-month fish exposure experiment using artificially-contaminated food. Calculations are based on concentrations estimated in whole fish body

766

\begin{tabular}{lccc}
\hline Congener & $\begin{array}{c}\text { Accumulation rate } \\
10^{-2} \mathrm{ng} / \mathrm{g} / \mathrm{day}\end{array}$ & $\begin{array}{c}\text { Depuration rate } \\
10^{-2} \mathrm{ng} / \mathrm{g} / \text { day }\end{array}$ & $\begin{array}{c}\text { Half-life } \\
\text { days }\end{array}$ \\
\hline Tetra-1 & $0.60 \pm 0.07$ & $0.63 \pm 0.33$ & $110 \pm 57$ \\
BDE-49 & $4.38 \pm 0.17$ & $0.60 \pm 0.23$ & $115 \pm 44$ \\
Penta-1 & $3.05 \pm 0.08$ & $1.17 \pm 0.21$ & $59 \pm 11$ \\
Hepta-1 & $0.22 \pm 0.01$ & $1.44 \pm 0.44$ & $48 \pm 15$ \\
BDE-202 & $0.09 \pm 0.01$ & $0.80 \pm 0.23$ & $86 \pm 25$
\end{tabular}

${ }^{\mathrm{a}}$ Depuration rates were calculated using the exponential part of the curve 
Figure 1

PBDEs spiked in food
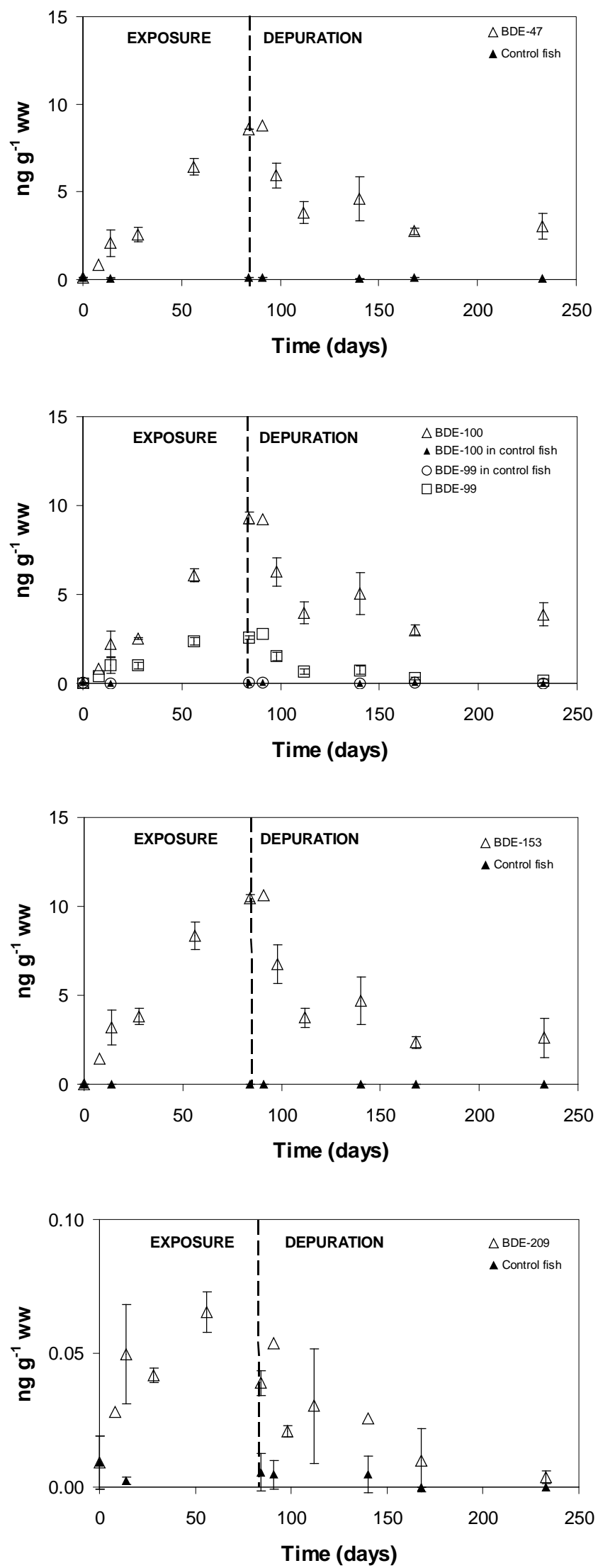

Debrominated PBDEs
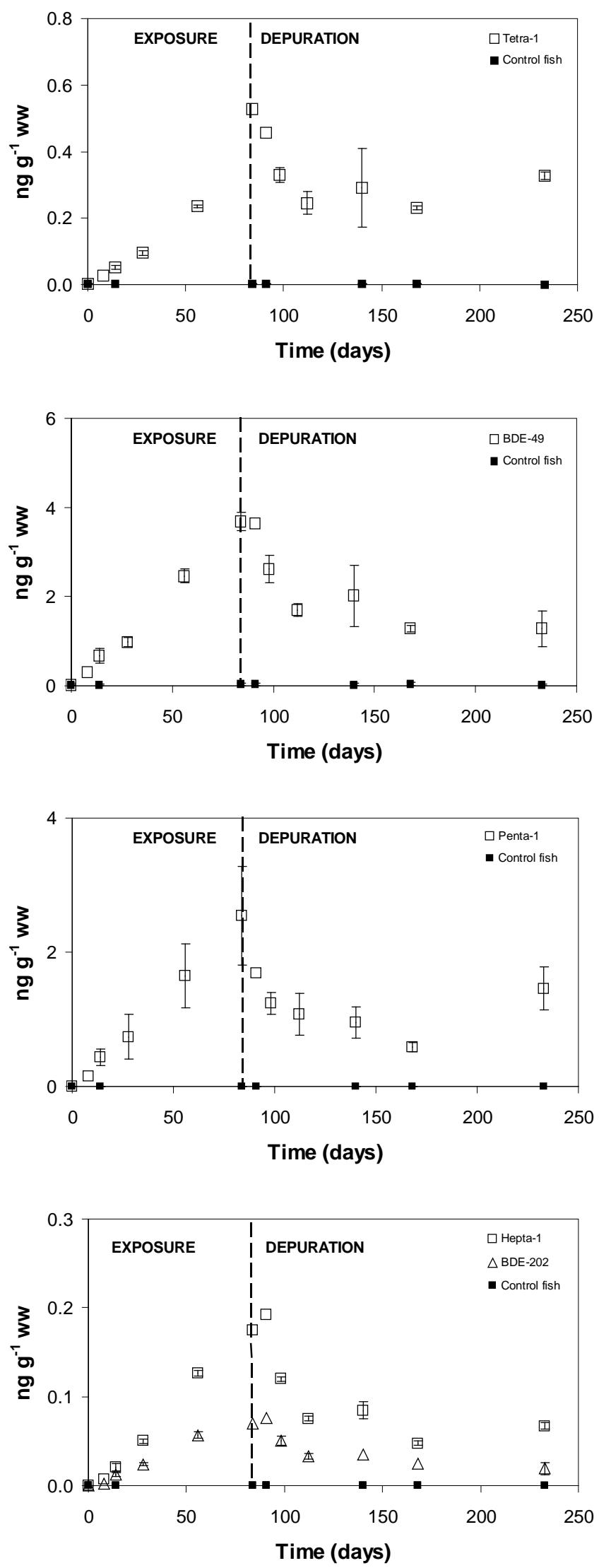
Figure 2
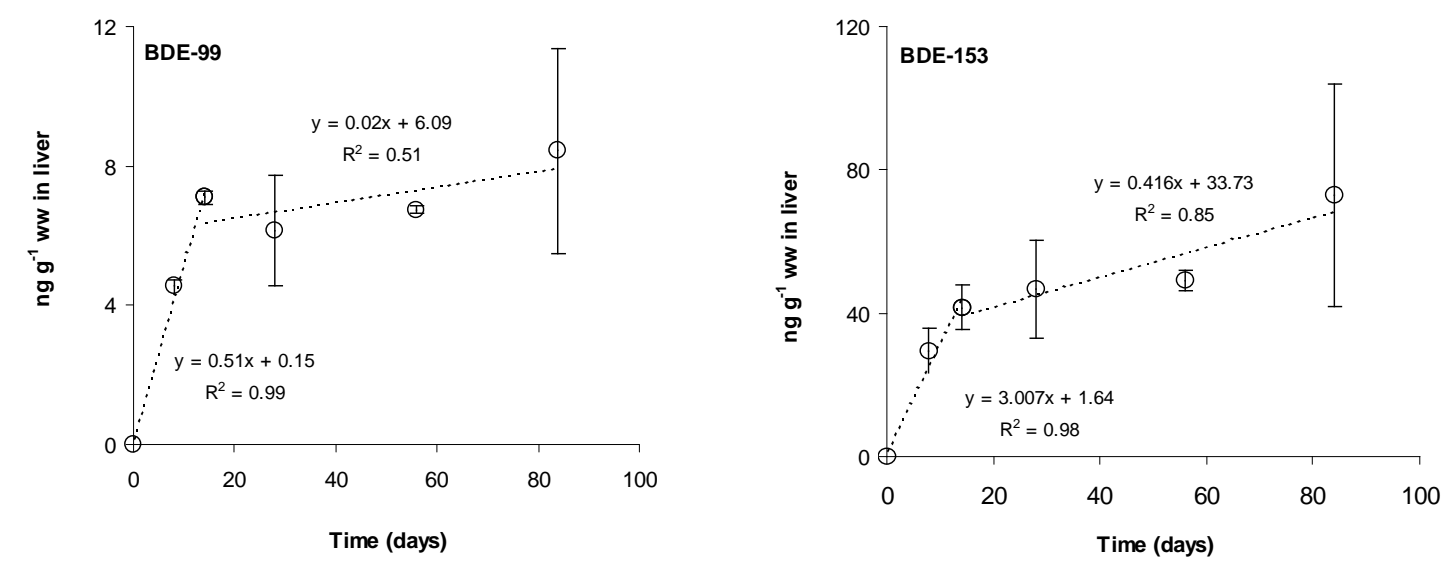
Figure 3

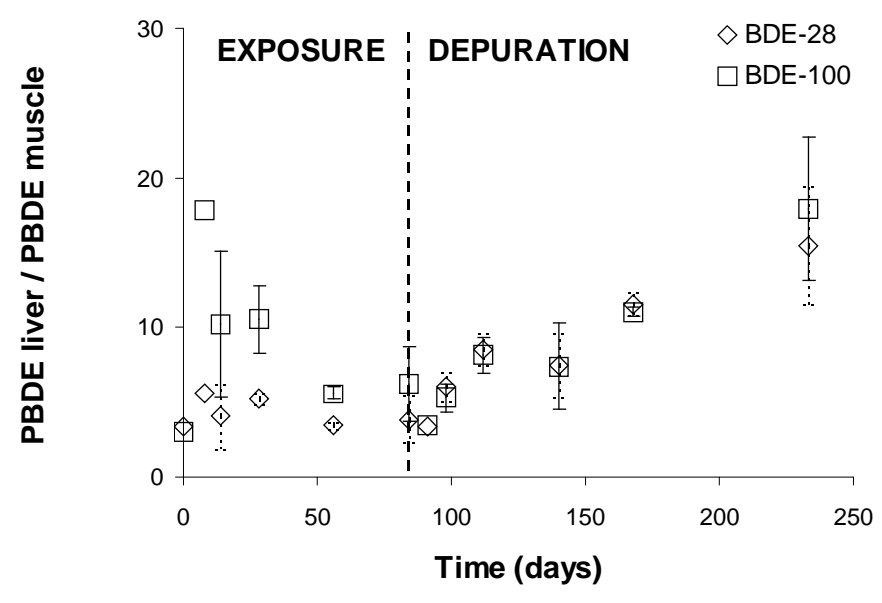


Figure 4

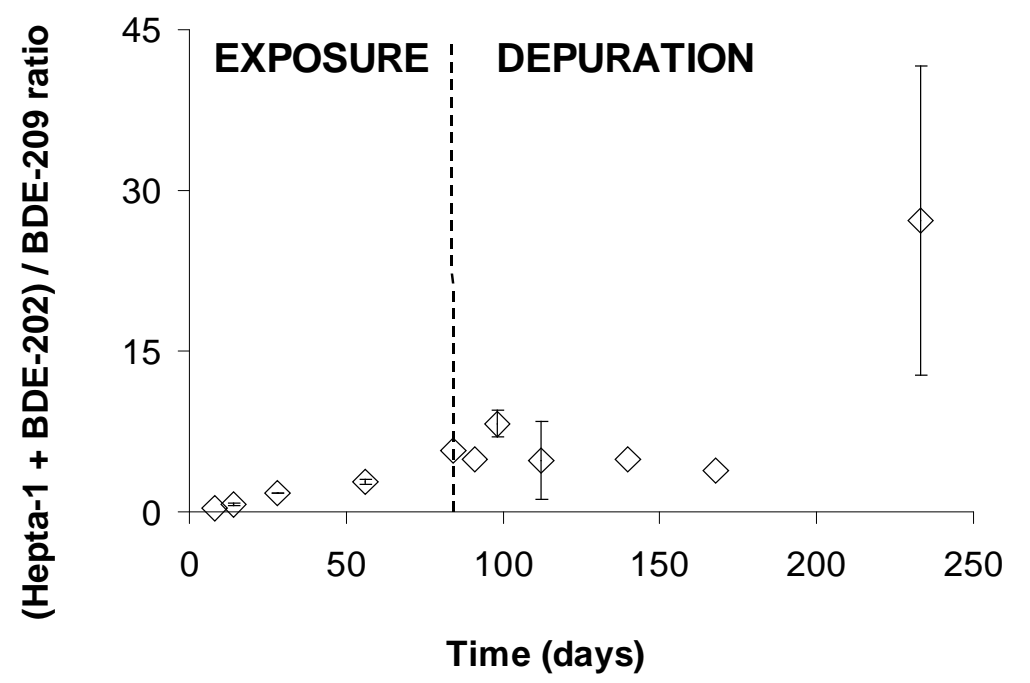


Figure 5

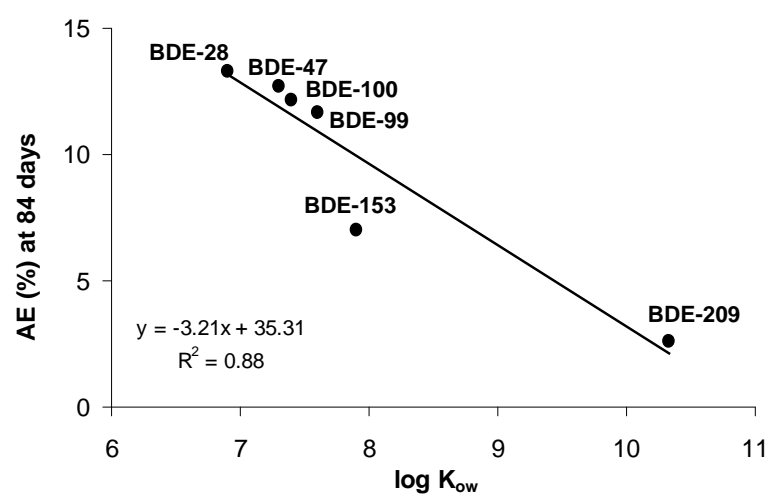

